\title{
The European Union as a Trigger of Discursive Change: The Impact of the Structural Deficit Rule in Estonia and Latvia
}

\begin{abstract}
Our paper explores how a rule prescribed by the European Union can bring about changes in the policy discourse of a member state. Drawing on the literatures of discursive institutionalism and Europeanization, the theoretical part discusses the factors that influence discursive shifts. The empirical part examines the discursive impacts of the introduction of the structural budget deficit rule, required by the Fiscal Compact, in Estonia and Latvia. It demonstrates how the discursive shifts have been shaped by the localized translations offered by civil servants, the entrance of additional actors to the policy-making arena, crisis experience, and the strategic interests of policy actors.
\end{abstract}

KEYWORDS: Discursive institutionalism, Europeanization, fiscal policy, fiscal rules, crisis.

RECEIVED 12 June 2017; ACCEPTED 30 July 2018.

\section{INTRODUCTION}

There is a growing understanding in governance research that in order to explain institutional development and policy change, we need to pay attention to the role of ideas and discourse. Discursive institutionalism (e.g., Schmidt 2008, 2010, 2011) and related ideational research streams (e.g., Campbell 1998; 2004; Beland and Cox 2011; Carstensen 2011) have contributed significantly to giving ideas and discourse a more prominent position. Indeed, discursive institutionalism (DI) - a framework for analysis that focuses on the substantive content of ideas and the interactive processes of discourse in institutional context (Schmidt 2008, 2010) - has been considered to be more fruitful in exploring and explaining policy change than the other three institutionalisms (rational choice, historical and sociological), which tend to have more static orientations (Carstensen 2011; Crespy and Schmidt 2014; Schmidt 2009, 2011).

With the increasing role played by the European Union (EU) in the policy-making arenas of the European countries, especially in the new(er) member states, understanding the kinds of ideational and discursive impacts that the EU rules can have has become more important than ever. Most of the studies on Europeanization tend to focus on shifts in member states' policies themselves (Cowles et al. 2001; Börzel and Risse 2003), rather than on the ideational and discursive mechanisms that may act as drivers of change. As Schmidt and Radaelli (2004, p. 184) have emphasized, however, without examining the impact of the EU on the policy discourses of its member states, our understanding of Europeanization remains incomplete and we may miss more nuanced changes.

Thus, the focus of our paper is to continue the endeavour of synthesizing insights from the DI and Europeanization literatures, initiated by Schmidt and Radaelli (2004), and to explore - both theoretically and empirically - which factors influence the discursive shifts brought about by EU rules in the member states that are rule-takers. While Schmidt and Radaelli (2004) pointed to discourse as a causal factor that mediates the impacts of $\mathrm{EU}$ rules on the member states' policies, our paper examines the factors that influence

\footnotetext{
1 Professor of Public Finance and Governance, Ragnar Nurkse Department of Innovation and Governance, Tallinn University of Technology, Estonia. Email: ringa.raudla@ttu. ee, Address: Akadeemia 3, Tallinn 12618, Estonia.

2 Ragnar Nurkse Department of Innovation and Governance, Tallinn University of Technology, Estonia.

3 Ragnar Nurkse Department of Innovation and Governance, Tallinn University of Technology, Estonia.

4 Ragnar Nurkse Department of Innovation and Governance, Tallinn University of Technology, Estonia.
} 
discursive shifts induced by EU rules in the first place. As Lynggaard (2012, p. 97) notes, the effects of EU on domestic policy discourses is 'still an insufficiently researched area'.

As a first step - drawing on the existing literature on DI, related streams of ideational research and Europeanization studies - we provide a theoretical discussion exploring this question. As a second step, we use the theoretical framework for an empirical analysis of the factors that influenced the shifts in fiscal policy discourse brought about by the introduction of the EU-mandated structural budget deficit in the two member states: Estonia and Latvia. While the Maastricht deficit rules focused on the nominal deficit (essentially capturing a difference between budget expenditures and revenues), the Fiscal Compact (or the Treaty on Stability, Coordination and Governance), signed in March 2012 and enacted in 2013, required the member states to adopt a structural deficit rule, which is considerably more complex and takes into account the economic cycle and one-off budget measures (Iaonnou et al. 2015; Mourre et al. 2014). The case selection for our empirical study was based on the following considerations.

First, since the structural deficit rule prescribes a focus on the cyclical stance of the budget and entails a counter-cyclical role for fiscal policy, it would be insightful to examine the impacts of that new rule on polities where fiscal policy-making has hitherto focused on the nominal stance of the budget and has been pro-cyclical. Since regaining independence in the 1990s, the fiscal policy-making in both Estonia and Latvia has focused on the nominal balance and has tended to be pro-cyclical (Kattel and Raudla 2013). Based on the observations of historical institutionalism, pointing to path-dependence of policies (e.g., Pierson 2000), and arguments from the Europeanization literature, referring to the member states' resistance to the externally imposed rules and ensuing inertia in policymaking (Börzel and Risse 2003, 2009; Cowles et al. 2001), it could be expected that the fiscal policy discourse in those two countries would remain unchanged - since the new rule clashes with the existing notions of fiscal policy-making. Our empirical study shows, however, that the compliance with the new rule in those two countries has not been merely 'formal' (or 'symbolic') but, instead, we can observe significant shifts in the fiscal policy-making discourse in both countries (with Estonia witnessing a more extensive shift than Latvia, extending also to the communicative realm).

Second, in the context of the Fiscal Compact, these countries could be viewed as 'rule-takers', meaning that they had limited (if any) influence on the content of its provisions. That enables us to examine the discursive effects of a rule that can be viewed as 'externally required'.

Third, because of their similar historical legacies, Estonia and Latvia can be regarded as 'the most similar' cases. This allows us to explore how their small differences may have influenced the discursive shifts. For example, Estonia has been praised as the 'posterchild' of fiscal conservatism in Europe (e.g., Raudla and Kattel 2011), whereas Latvian fiscal policy has been somewhat more 'lax'. Estonia came through the crisis of 2008-2009 'on its own', whereas Latvia needed financial assistance from the EU and the IMF.

As sources of data for the two cases, we used semi-structured interviews with civil servants working in the finance ministries, policy documents, verbatim records of the legislative debates, and media articles, covering the period of 2013-2015. The semistructured interviews (6 from Estonia and 5 from Latvia) were conducted between August 2014 and October 2015. The paper is structured as follows: Section 2 outlines the theoretical arguments, followed by empirical analysis in Section 3. Section 4 discusses the findings and provides the conclusions.

\section{THEORETICAL DISCUSSION}

While the existing studies blending DI with Europeanization (e.g., Schmidt and Radaelli 2004) have focused on how - in the chain of external rules-discourse-policy - discourse influences policy, we focus on the first link of that sequence. Thus, the core question of our paper is: which factors influence the discursive shifts that are brought about by EU rules in member states in the first place? We are specifically interested in the discursive shifts in those member states that are 'rule-takers': where the domestic officials have not been able to exert extensive influence on the content of the rule(s). Such situations would allow us to examine the 'rules-discursive change' link in a more 'pure' form. In the case of those member states that have played a bigger role in changing the EU rules, the discursive shifts may have preceded the rule change, hence making the analysis more muddled.

When we say that an EU rule triggers discursive changes in a member state, what do we mean by it? How can discursive shifts be gauged? According to DI, discourse has ideational and interactive dimensions. The ideational dimension refers to the content of policy ideas (e.g., about the soundness and appropriateness of policy programmes), whereas the interactive dimension captures 'processes of policy formulation and communication that serve to generate and disseminate those policy ideas' (Schmidt and Radaelli 2004, p. 


\section{Sciendo}

193). Thus, in tracking discursive shifts triggered by an external rule, we should look at both realms. In the ideational domain, shifts can take the form of changes in cognitive arguments about the causal logic of a policy and also in policy goals and instruments that are considered to be normatively acceptable by policy actors (Schmidt 2002, 2008; Campbell 1998). With regard to the interactive dimension, Schmidt (2008) distinguishes between two types of discourse: coordinative and communicative. Coordinative discourse takes place between policy-makers and is aimed at policy construction and elaboration (Schmidt 2008, 2011). Thus, shifts in this realm can be reflected as changes in the range of policy alternatives considered, rhetorical actions taken and the density of discursive interactions. Communicative discourse is directed from policy-makers to the electorate and aims to persuade the public that a chosen policy is necessary and desirable (Schmidt 2008, 2011). Changes in this domain can be reflected not only in the substantive policy ideas communicated to the public but also in the frequency of bringing up a policy message.

Coming now to our core question: which factors influence the discursive shifts that are brought about by EU rules in member states? Synthesizing the insights from the DI and Europeanization literatures, we can point to the following possible modes.

First, one of the central arguments of the Europeanization studies is that the impacts of EU rules depend on their 'goodness of fit' with the existing national policy legacies (Cowles et al. 2001; Börzel and Risse 2003; Radaelli 2003; Risse et al. 2001). From the perspective of DI, however, the degree of the 'goodness of fit' is politically constructed (Schmidt 2008, 2011). Thus, bringing together these two approaches, we can argue that if a 'misfit' between the new rule and existing policies is construed as 'too large' in the coordinative discourse, policy actors may prefer 'inertia' (or even 'retrenchment') in dealing with the new rule and seek to avoid drawing attention to the issue in the communicative discourse. If, however, the gap is construed as 'moderate', ideational shifts can result from the attempts of the national level policy actors to deal with the 'adaptational pressure' (Cowles et al. 2001) - both in the coordinative and communicative domains - by 'localizing' the rule via discursively increasing its congruence with the existing legacies (Skogstad and Schmidt 2011). In order to 'localize' the externally imposed rule, policy actors can attempt to 'layer' it on the existing institutions (Schmidt 2009; Lynggaard 2012) via discursively creating a 'bricolage' of the old and new rules (Carstensen 2011; Schmidt 2014; Campbell 2004). They can accommodate the new rule by 'explaining how it fits with the prevalent traditions', 'recombining' the ideas to blend in new elements (Campbell 2005), and 'infusing' it with contextualized meanings (Schmidt 2010).

Second, the level of complexity of the EU-imposed rule is likely to condition its discursive impacts. With regard to the ideational domain, the clearer and simpler the rule, the higher the cognitive ease of absorbing it (Campbell 1998). If the rule is highly complex or technical, it is likely to generate political discussions when political actors attempt to flesh out its meaning in the coordinative discourse. However, if the rule is too technical and complex, it may not exceed the 'boredom threshold' and could hence fail to gain traction in the communicative domain (Busch 2004).

Third, as DI emphasizes, discourse has to be examined in the institutional context of the polity (Beland and Cox 2011; Campbell 1998, 2004; Schmidt 2008, 2010). The same applies to discursive shifts. Political institutions can play an important role by constraining or enabling access to policy-making arenas, shaping the modes of interaction in these arenas, and influencing 'who talks to whom' (Schmidt and Radaelli 2004, p. 197). For example, in policy arenas characterized by multiple (veto) actors and centres of authority, we can expect more extensive coordinative policy discourse than in those with more 'simple' constellations of actors (Schmidt 2008, 2009, 2010). Importantly, as the Europeanization literature has pointed out, externally imposed EU-rules can increase the number of policy actors who take part in discussions over a policy area (Börzel and Risse 2003), which, in turn, can give rise to thicker and more elaborate coordinative discourses. Furthermore, an externally imposed rule can empower certain policy actors vis-à-vis others, and hence, strengthen their 'voice' (and potential influence) in the coordinative discourse.

Fourth, given the increasing immersion of civil servants from the national governments in the policy-making processes of the EU, they can play a significant role in acting as carriers of the policy ideas originating from the EU (Trondal 2001) and 'translating' a new rule into the local context (Campbell 2004; Gutierrez 2010). In particular, civil servants can play an important role in offering the localized (re)interpretations of the external rules - especially in policy areas that are highly complex and technical (Gutierrez 2010; Irvine 2011). They can, therefore, influence policy alternatives considered in the domestic coordinative discourse and also persuade politicians of the normative acceptability of the policy ideas embodied in the rule. Thus, via frequent contact and interaction or 'elite networking' (e.g., at the meetings in Brussels) as a socialization mechanism (Busch 2004; Börzel and Risse 2003; Radaelli 2003), civil servants can 'buy' into the EU rules (even if the new rule diverges from the existing policy legacies) and attempt to persuade elected officials through interactions in coordinative discourse, for example, by offering specific interpretations of a more general idea, 'attaching' desirable connotations to the idea, and drawing out its implications for policy action. The stronger the position of 
the civil servants in the policy-making process, the more extensive their influence on the discursive shifts are likely to be (Barnett and Finnemore 2004).

Fifth, an EU rule is more likely to bring about discursive shifts (in both ideational and interactive dimensions) after the member state has experienced a major crisis. The experience of a crisis can open a 'window of opportunity' for discussing new (or at least different) policy ideas in coordinative and communicative domains. The 'trauma' of a crisis can allow policy actors to construe the new rule as a potential solution to problems that had given rise to the crisis and, through that, enhance its normative acceptability (e.g., Blyth 2002, 2007; Busch 2004; Crespy and Schmidt 2014; Campbell 2004).

Finally, the effects of an EU rule on policy discourse in a member state can be mediated by the interests of policy actors. An important observation emerging from DI is that we should pay careful attention to the possible interactions between ideas and interests (see, e.g., Beland and Cox 2001; Blyth 2002; Campbell 1998, 2004; Schmidt and Radaelli 2004; Schmidt 2009). In the case of EU-mandated rules, policy actors can use them to gain strategic advantage. If the new rule serves the interests of at least some policy actors, they are more likely to use it for legitimizing their (interest-based) policy proposals (or decisions) both in the coordinative and communicative domains of discourse. Conversely, potential controversies connected to the new rule can also be used as 'ammunition' by politicians when attacking their opponents in interactive and communicative realms.

In order to examine the plausibility of the theoretical conjectures outlined above, we will next analyse the discursive effects of an EU rule - the structural deficit target - in Estonia and Latvia.

\section{THE EMPIRICAL STUDY}

Following the methodological recommendations of the existing studies on DI (e.g., Busch 2004; Lynggaard 2012; Schmidt and Radaelli 2004; Schmidt 2014; Crespy and Schmidt 2014) we used the following sources of data for our study: semi-structured interviews with civil servants working in the finance ministries, policy documents, verbatim records of the legislative debates and media articles from 2013 to 2015.

The interviews and policy documents were used for gaining insights about ideational shifts and the changes in coordinative policy discourse, spurred by the adoption of the structural deficit rule. In particular, we were interested in whether the civil servants observed (and whether policy documents also reflected) more elaborate coordinative discourse on fiscal policy after the adoption of the rule and whether there have been any ideational changes (e.g., in the normative acceptability of counter-cyclical fiscal policy). The analysis of the content of legislative debates and media articles was conducted with the view to identifying any shifts in the national governments' communicative discourse directed towards the local electorate regarding fiscal policy.

The semi-structured interviews (6 from Estonia and 5 from Latvia) were carried out between August 2014 and October 2015. The interviews were conducted with the finance ministry officials who are in charge of the fiscal policy. Since the fiscal policy departments of the finance ministries in Estonia and Latvia are relatively small, 5-6 interviews per country were deemed sufficient for generating empirical insights. In both cases, the fiscal policy department has 15 employees, with 7-8 officials mostly in charge of technical analytical work. Hence, we covered the perceptions of most of the officials in policy-making positions (and also one technical analyst in both cases). The interviews, usually lasting 1-3 hours, were recorded and transcribed. For the media articles, the main daily newspapers in Estonia and Latvia were searched, using key words 'structural balance' and 'structural deficit' for the time-frame of 2013-2015. The newspapers covered in Estonia were Postimees, Päevaleht, and Äripäev, and in Latvia Latvijas Avize, Diena, and Neatkariga Rìta Avize. In the period of 2013-2015, the structural balance was discussed in 12 media articles in Estonia and 8 articles in Latvia. The same search words were used for screening the verbatim records of the parliaments in Estonia and Latvia between 2013 and 2015. In the Estonian parliament, the structural balance rule was first discussed in three different readings of the organic budget law (6 November 2013; Verbatim record 15 January 2014; 19 February 2014) and subsequently debated in eight legislative sessions, which were mostly information sessions, where legislators can question ministers (24 March 2014, 9 April 2014, 2 June 2014, 4 June 2014, 10 June 2014, 19 November, 10 December 2014, 17 December 2014). ${ }^{5}$ In Latvia, the structural deficit was discussed in three readings of the Fiscal Responsibility Law, adopted in 2013 (12 January 2012; 20 December 2012; 31 January

5 All the verbatim records of legislative sessions are available at http://stenogrammid.riigikogu.ee/ 
2013), during the discussion of the medium term budget framework for 2013-2015 (22 October 2012), and subsequently in two readings of the Law on Stabilisation Reserve (30 January 2014; 20 March 2014). ${ }^{6}$

\section{Background information on Estonia and Latvia}

\section{Economic context}

Despite common policy legacies and similar trajectories of economic development since regaining independence in 1991, the fiscal indicators of Estonia and Latvia show somewhat different dynamics over the past 15 years. While Estonia has recorded a nominal budget deficit in 4 out of 15 years, the Latvian budget has been in deficit in all 15 years (see Table 1). Also, the Estonian government debt has been significantly lower than that of Latvia; the significant jump in the Latvian debt in 2008-2010 was caused by the bailout of the Parex Bank by the Latvian government (Kattel and Raudla 2013). It is noteworthy that the nominal budget deficit in Estonia remained below 3\% of GDP even in 2009, when the real GDP fell by $14.7 \%$ (see Table 1). As pointed out by Raudla and Kattel (2011), the fiscal policy discourse in Estonia since the early 1990s - and which continued during the crisis of 2008-2009 - has been characterized by extreme fiscal conservatism and commitment of all political parties to avoiding (nominal) budget deficits. As they explain, this has been driven by the underlying belief of the political actors that balanced budgets and low debt help to guarantee macroeconomic stability and encourage economic development. While the Latvian government's deficit has remained under the Maastricht criterion of 3\% of GDP in all but crisis years, it has not aspired to maintain the nominal balance or even achieve surplus like the Estonian government.

Tab. 1: Fiscal and economic indicators for Estonia and Latvia 2000-2015.

\begin{tabular}{|c|c|c|c|c|c|c|}
\hline Year & $\begin{array}{l}\text { Budget deficit } \\
\text { in Estonia (\% of } \\
\text { GDP)* }\end{array}$ & $\begin{array}{l}\text { Budget deficit } \\
\text { in Latvia ( } \% \text { of } \\
\text { GDP) }\end{array}$ & $\begin{array}{l}\text { Public debt in } \\
\text { Estonia (\% of } \\
\text { GDP) }\end{array}$ & $\begin{array}{l}\text { Public debt in } \\
\text { Latvia (\% of } \\
\text { GDP) }\end{array}$ & $\begin{array}{l}\text { Real GDP } \\
\text { growth in } \\
\text { Estonia }\end{array}$ & $\begin{array}{l}\text { Real GDP } \\
\text { growth in Latvia }\end{array}$ \\
\hline 2000 & 0.0 & -2.8 & 5.1 & 12.2 & 6.4 & 6.4 \\
\hline 2001 & 0.1 & -2.0 & 4.8 & 14.0 & 6.8 & 8.5 \\
\hline 2002 & 0.4 & -2.2 & 5.7 & 13.2 & 6.8 & 8.5 \\
\hline 2003 & 1.8 & -1.6 & 5.6 & 13.9 & 7.5 & 8.6 \\
\hline 2004 & 2.4 & -1.0 & 5.1 & 14.2 & 6.5 & 8.9 \\
\hline 2005 & 1.1 & -0.4 & 4.5 & 11.7 & 9.5 & 10.2 \\
\hline 2006 & 2.9 & -0.6 & 4.4 & 9.9 & 10.4 & 11.6 \\
\hline 2007 & 2.5 & -0.6 & 3.7 & 8.4 & 7.9 & 9.8 \\
\hline 2008 & -2.7 & -4.0 & 4.5 & 18.6 & -5.3 & -3.2 \\
\hline 2009 & -2.2 & -9.0 & 7.0 & 36.4 & -14.7 & -14.2 \\
\hline 2010 & 0.2 & -8.1 & 6.5 & 46.8 & 2.5 & -2.9 \\
\hline 2011 & 1.2 & -3.3 & 6.0 & 42.7 & 8.3 & 5.0 \\
\hline 2012 & -0.2 & -0.8 & 9.7 & 40.9 & 4.7 & 4.8 \\
\hline 2013 & -0.2 & -0.7 & 10.0 & 38.2 & 1.6 & 4.2 \\
\hline 2014 & 0.6 & -1.4 & 10.6 & 40.0 & 2.1 & 2.4 \\
\hline
\end{tabular}

*Net lending (+)/net borrowing (-).

Source: Eurostat

6 All the verbatim records of legislative sessions of the Latvian parliament are available here: http://www.saeima.lv/lv/transcripts/category/17 (for the 11th Saeima) and http://www. saeima.lv/lv/transcripts/category/19 (for the 12th Saeima). 
In international discussions on fiscal policy, both countries, however, have been regarded as the 'poster-children' of austerity owing to the extensive fiscal consolidation measures undertaken in the midst of a deep economic recession in 2008-2010 (Kattel and Raudla 2011; Lütz and Kranke 2014). Given the pro-cyclical nature of the fiscal policy in both countries since the early 1990s, it would be particularly insightful to examine what happened to the fiscal policy discussions after the adoption of a fiscal rule requiring a counter-cyclical focus for fiscal policy.

\section{Political context}

Since regaining independence in 1991, Estonia has always had coalition governments, consisting of 2-3 parties. After the March 2011 elections, just as the country was exiting the economic crisis, the two main right-leaning parties - the Reform Party (RP), which emphasizes market liberalism, and the Pro Patria and Res Publica Union (PPRPU), which is also pro-market but also emphasizes more conservative values and has been the staunchest advocate of fiscal discipline among the Estonian parties - formed a coalition government. These two parties had been responsible for the harsh austerity measures in 2008-2010, undertaken in order to keep the budget deficits below 3\% of GDP (as required by the Maastricht rules) and to qualify for the Eurozone. Despite the social implications of these measures (including a skyrocketing unemployment rate), the parties emerged victorious from the 2011 elections and were able to form a coalition.

In March 2014, however, the coalition broke up and the RP (which had the largest number of seats in the parliament) formed a new coalition with the SD, which is one of the left-leaning parties in Estonia. The coalition agreement signed by the two parties entailed a list of promises, reflecting their desire to appeal to their electorates before the upcoming elections in March 2015. The worsening economic projections (due to the Ukraine crisis) after the signing of the coalition agreement, however, meant that the revenue projections had to be lowered. In order to cover all the expenditures (including the pre-election promises), the government had to plan the draft budget with a nominal deficit. The fact that the new coalition government went against the political norm of balanced budgets, which had been the anchor of Estonian economic policy since the early 1990s, was used by the fiscally conservative PPRU, now in the opposition, to attack the government continuously before the 2015 March elections. After the 2015 elections, the three parties - the RP, the PPRU and the SD - formed a new coalition government.

Similar to Estonia, Latvia has always had coalition governments, ranging from 2 to 7 parties. Since regaining independence, only centre-right and right-leaning parties have been represented in coalition governments. Following the financial crisis in the fall of 2008, which led to the collapse of one of the largest banks in Latvia, the government of Prime Minister Godmanis fell in February 2009, paving the way for Valdis Dombrovskis to become the longest serving prime minister in Latvia's history. One of the characteristics of all the governments prior to the one led by Dombrovskis was the propensity to engage in pro-cyclical fiscal policy: whenever the times were good, new spending measures or tax reductions were often proposed. Dombrovskis was proposed as a crisis minister, a technocrat with the necessary credentials - he had been the chief economist at the central bank and also a finance minister - someone who could be trusted by the international institutions, but was also considered somewhat of an outsider in Latvian politics. Dombrovskis led three subsequent centre-right coalition governments from March 2009 until November 2013 and was responsible for the hard austerity measures implemented during the deepest recession in Europe, under the conditionality imposed by a consortium of external lenders led by the IMF and the EU. The 2011 elections, which followed after the President of Latvia Valdis Zatlers announced a referendum on the dissolution of the parliament on the grounds of corruption and disregard for the rule of law by some members of the parliament. The elections following the referendum led to the overall win for the centre-left party Unity Centre; however, the centre-right parties formed a coalition with the right-wing nationalists (For Fatherland and Freedom/LNNK), making it possible for Dombrovskis to continue with the implementation of reforms and austerity measures. Dombrovskis achieved his ultimate objective of Latvia joining the Eurozone.

An interesting alliance formed during the first reading of the Fiscal Discipline Law in 2012, when the nationalists joined forces with their primary enemy, the Unity Centre, in criticizing the initially proposed method for calculating the budget deficit. In their view, the method did not address cyclical shocks; so they argued that the approach should have a more pronounced countercyclicality. The Fiscal Discipline Law that was eventually adopted in 2013 was based on the Fiscal Compact. 


\section{The adoption of structural balance/deficit rule}

Before the enactment of the Fiscal Compact, neither Estonia nor Latvia had formal fiscal rules stipulating budget balance or deficit targets. The Maastricht criteria, which had guided the fiscal policy in both countries, stipulated a nominal budget deficit rule, stating that it should not exceed 3\% of GDP. The Fiscal Compact (enacted in 2013) required the members of the Eurozone to introduce a structural deficit ceiling in their domestic legislation. Simply put, the nominal budget position reflects the difference between budget expenditures and revenues, that is, if the expenditures exceed the accrued revenues, the budget is considered to be in deficit. The structural budget deficit rule is more sophisticated: it takes into account the economic cycle and also whether the expenditures and revenues are regular or just one-off and temporary. The cyclically adjusted budget position is found by subtracting the cyclical component (or the output gap) from the nominal budget position (for a more detailed discussion, see Mourre et al. 2014). Thus, if the economy is in recession, the budget can record a nominal deficit but, after incorporating the cyclical component, it should be in a nominal balance or surplus. Also, by accounting for one-off and temporary transactions, the structural deficit entails information about whether the match between the revenues and expenditures is sustainable: if a windfall revenue is used for covering expenditures, the budget may not record a nominal deficit but it may indicate a structural deficit, reflecting the fact that one-off revenue might not be available over the next years to cover foreseen expenditures.

The new State Budget Act of Estonia, adopted in early 2014, established a stricter rule than prescribed by the Fiscal Compact and required the structural budget position to be 'in balance or in surplus'. As the interviewed finance ministry officials explained, the drafters of the law hoped that the structural balance - rather than deficit - requirement would provide a 'buffer', just in case the calculations by the Ministry of Finance $(\mathrm{MoF})$ deviate from those of the European Commission (EC). When the drafts of the new organic budget law were debated in the Estonian parliament in 2013-2014, the structural balance rule was discussed on three different occasions (Verbatim record 6 November 2013; 15 January 2014; 19 February 2014). When introducing the provision, the finance minister (RP) and the chairman of the finance committee (PPRU) emphasized that the need to adopt that rule comes from the Fiscal Compact and that, from the point of view of economic theory, it is a correct approach (6 November 2013). The subsequent legislative debates focused on the technical complexities involved in calculating the structural position and how the real time estimations may differ from the ex post assessments (e.g., Verbatim record 15 January 2014; 19 February 2014). As Erkki Nestor (SD) noted, 'The calculation of structural balance is like a black box and the members of the parliament may not understand it.' (Verbatim record 15 January 2014). This was countered by the chairman of the finance committee (PPRU), Sven Sester, who argued, 'If members of parliament do not understand what structural balance is, they have to ask for advice about how to interpret it. There is no shame in asking for advice.' There was also some discussion on whether a structural balance requirement should be preferred over a nominal balance rule and how it is also important to pay attention to the nominal stance (Verbatim record 6 November 2013; 19 February 2014). Aivar Sóerd (RP) emphasized that although the organic budget law establishes a structural balance rule, it is also important to observe the nominal position, especially since the calculation of the structural stance is based on estimates and it is complicated to assess the output gap (Verbatim record 19 February 2014). Generally, however, there was very little discussion about the structural balance rule; the elected officials (i.e., politicians in the cabinet and also in the parliament) simply accepted that since the Fiscal Compact required such a rule, it had to be incorporated into the domestic legislation.

Latvia's new Fiscal Responsibility Law, passed in early 2013, stipulates that the structural budget deficit of the annual budget should not exceed $0.5 \%$ of GDP. Compared to the parliamentary deliberations in Estonia, where the necessity of incorporating the structural balance rule was not questioned (even by the opposition), there were more extensive debates about the desirability of such a fiscal rule in the Latvian legislature. In the discussions over the rule, concerns were voiced by the opposition about it being too restrictive and limiting Latvia’s ability to incur loans in order to promote economic development. As MP Pimenovs (Concord, centreleft party) argued, 'The interest of Latvia is to develop faster, to make sure that our investment in the economy is greater. This would also mean that our wealth is growing faster than our debt. And $0.5 \%$ is just not enough in order to make this possible.' (Verbatim record 31 January 2013). In addition, like in Estonia, concerns were voiced about the inaccuracies involved in calculating the cyclical component of the structural deficit (Verbatim record 20 December 2012). At the same time, the inclusion of the structural deficit rule in the fiscal discipline law was supported by the MoF officials and also the Prime Minister, in the hope that it would allow for counter-cyclical fiscal policy, whereas prior to the introduction of this requirement, fiscal policy had always been pro-cyclical. Thus, with reference to the Fiscal Compact, it was written into the domestic legislation. 
Several interviewees from both Estonia (4 out of 6 interviewees) and Latvia ( 3 out of 5 interviewees) stated that the introduction of the structural balance/deficit rule can be considered to be one of the biggest reforms in the fiscal policy arena in recent years (the higher up in the organizational hierarchy, the more the interviewees supported that statement). At the same time, the interviewed officials noted that without the Fiscal Compact, the structural deficit (or balance) target would not have been written into domestic legislation. The reasons for that, however, were different in the two countries. In Estonia, the interviewed civil servants felt that there was actually no need for such a rule, given the political culture of fiscal conservatism. They also noted that if a fiscal rule had to be established at all, the local preference would have been for one with a nominal - rather than structural - target. Although in Latvia, the discussions over the draft fiscal discipline law, which started in 2011, included the possibility of establishing a deficit target with a cyclical component, it was the Fiscal Compact that ensured that the structural deficit requirement was actually written into the law. Thus, according to the interviewed officials, in both cases, the governments could be viewed as rule-takers, having had only limited influence over the substantive provisions of the Compact.

\section{The impact of the structural balance/deficit rule on fiscal policy discourse}

In this section, we first give an overview of what changed in the fiscal policy discourse in both countries after the adoption of the structural deficit rule, and then discuss which factors played a role in inducing these shifts.

\section{Discursive shifts}

\section{Estonia}

The structural balance rule has triggered clear shifts in both the ideational and interactive domains of fiscal policy discourse in Estonia. Most of the interviewed Estonian officials (5 out of 6 ) noted that after the adoption of the structural budget balance rule, the main focus of fiscal policy-making has switched from the nominal balance to the structural position. Furthermore, not only has structural balance become the cognitive yardstick that policy actors have to acknowledge, it has also brought about a shift in the normative ideas about what a 'good' fiscal policy should look like. Before the adoption of the structural balance rule, even if the relationship between the annual budget and the economic cycle was discussed (e.g., during the crisis in 2008-2009), the policymakers had been sceptical or even expressly negative of using the public budget for stabilizing the economy (see Raudla and Kattel 2011). After the enactment of the new rule, however, the main policy actors (in the finance ministry, cabinet, and the legislature) started to consider using the budget in a counter-cyclical way. Most of the interviewed officials ( 5 out of 6 ) considered the focus on the structural balance to be a better guideline for fiscal policy than just looking at the nominal balance. They argued that by adhering to nominal balance, fiscal policy would be pro-cyclical, whereas structural balance is more informative and allows for smoothing the economic cycle. Indeed, the same MoF civil servants, who in 2008-2009 supported austerity measures in the midst of a deep economic crisis in order to avoid a nominal deficit, stated in our interviews in 2014-2015 that if a crisis were to hit Estonia again, the 'right' policy would be to go into nominal deficit in order to maintain expenditure levels.

These ideational shifts stand in clear contrast to the previous cognitive and normative ideas that had guided the fiscal policymaking in Estonia since the early 1990s. The introduction of the structural balance rule has allowed the policy-makers in Estonia to take a somewhat more 'relaxed' stance in the fiscal policy discussions. The predominant goal of fiscal policy since the early 1990s had been a nominally balanced budget, which was viewed as a political 'sacred cow' (Raudla and Kattel 2011). However, the insertion of the idea of structural balance into the fiscal policy-making arena has allowed the policy-makers to move away from the notion that the budget has to be always nominally balanced and to start accepting budget deficits when the economic conditions warrant it.

In addition to the above-mentioned ideational changes, we can also observe that the adoption of the structural balance rule has triggered shifts in the interactive realm of discourse - both in the coordinative and communicative domains.

The adoption of the structural balance rule has led to a denser coordinative discourse on fiscal policy. As our interviews indicate, the discussions between the MoF officials and politicians on fiscal policy have become more elaborate since the MoF has to explain at length what structural balance means, how it is calculated, and what budgetary stance should be adopted. Furthermore, given that the EC (i.e., the officials involved in coordinating the European semester and giving feedback about the medium-term strategies and draft budgets) and also the newly established Fiscal Council provide evaluations of the budgets of the member states (and assess 


\section{Sciendo}

their structural balance), they serve as additional actors in the coordinative discourse, further increasing the frequency of fiscal policy discussions, as noted by all interviewees.

Alongside the increased density of coordinative discourse, the structural balance rule has triggered clear shifts in the communicative discourse - directed towards the Estonian public. The discursive change can be most starkly observed when we compare the public statements of Jürgen Ligi (the Minister of Finance, RP) in 2009 and 2014. The same Finance Minister who, when advocating austerity measures in the middle of a major recession in 2009 claimed that 'If we do not have money, we cannot spend it.' (see Raudla and Kattel 2011), said in 2014: 'We shouldn't just look at whether we have money or not.' He stated further that 'Structural balance is not just a euphemism. ... This is what Europe follows in fiscal policy-making. ... It means that during bad times it is natural to have a nominal deficit. ... Having a nominal deficit during recession means that we do not exaggerate the economic cycle.' (Press conference of the Government of the Republic, 10 April 2014). The same Minister, who in 2009 advocated severe austerity measures, claimed in a media article in 2014 that 'If the economic forecast worsens, it does not mean we should immediately start cutting expenditures.' (Nael 2014; see also Tubalkain 2014). Similar arguments were presented by the Prime Minister Taavi Rõivas (RP) in legislative information sessions (Verbatim Record 2 June 2014, 4 June 2014, 8 September 2014). As we will explain below, this shift was facilitated by a change in the configuration of parties in the coalition government and the need to justify the nominal deficit incurred in order to finance pre-election expenditures.

Still, the idea of focusing on structural balance during fiscal policy-making has not been uniformly accepted by all the political actors in Estonia. It has triggered discursive confrontations in the communicative domain between the governing coalition (consisting of the RP and the SD) and the Pro Patria and Res Publica Union (PPRPU), which was in the opposition in 2014-2015, as witnessed by numerous media articles on structural balance (e.g., Sester 2014a,b), and also in the legislative debates (Verbatim records 24 March 2014, 9 April 2014, 2 June 2014, 4 June 2014, 10 June 2014, 17 December 2014).

The PPRPU, which has traditionally been the most fiscally conservative party, vocally criticized the use of structural balance as a yardstick for fiscal policy and argued that nominal balance should be taken more seriously both in the media (e.g., Hansalu 2014; Sester 2014a, b) and the legislative debates (Verbatim record 24 March 2014; 2 June 2014; 19 November 2014). Its representatives admonished the government in 2014 for giving up the goal of nominal balance and relaxing the fiscal stance by allowing nominal deficits for years 2014-2017. For example, MP Sester (PPRPU) emphasized in his speech at the parliament that 'Estonian people are used to understanding the budget in nominal terms: do we have enough means to cover our needs?' (Verbatim Record 2 June 2014). MP Toomas Tóniste (PPRPU) argued, 'After the PPRPU was thrown out of the coalition, the government has relaxed its fiscal stance and given up the nominal balance for the sake of pre-election gains.' (Verbatim Record 19 November 2014). In addition, the PPRPU representatives pointed out repeatedly in the parliamentary sessions that the MoF estimates of the structural position diverged from the EC projections, which were more pessimistic (Verbatim Record 4 June 2014, 8 September 2014, 19 November 2014, 17 December 2014). In response to that, the government ministers from the RP and the SD emphasized that Estonia still maintains conservative fiscal policy and keeps the budget structurally balanced, even if it was nominally in deficit, and that structural balance indicated sustainability in the long term (Verbatim Record 2 June 2014, 19 November 2014; 17 December 2014).

\section{Latvia}

According to all the interviewed officials, the structural deficit rule has brought about a significant ideational shift in the fiscal policy discussions within the MoF in Latvia. Pre-crisis fiscal policy-making was oriented towards following the Maastricht deficit criterion, and the discussions during the crisis itself were strongly influenced by the bailout programme from the EC and the IMF. After the enactment of the structural deficit rule, however, fiscal policy-making has started to pay closer attention to the cyclical role of the budget and also the longer-term sustainability of public finances. While previously, the focus of fiscal policy-making had been on observing the nominal budget position, the structural deficit requirement shifted attention to the structural position, according to the interviewed officials. Like in Estonia, the MoF officials in Latvia considered the structural position to be a better normative guide for fiscal-policy making. In the words of one official, 'Even though we can criticize the indeterminacies involved in calculating it, it is the best option available for guiding fiscal policy.... It is the only rule that addresses the tendencies to spend pro-cyclically.. (Interview L1). Thus, for the MoF officials, the pro-cyclical approach to fiscal policy making has been replaced by the idea of counter-cyclicality. While in Estonia, politicians have, for the most part, embraced structural balance as a desirable policy goal (and those who have not, think it is too 'lax', for allowing deficits), in Latvia, the politicians appear more reluctant. As one of the civil servants admitted, 'In the 
heads of politicians, it seems that the idea that there should be a strict framework with regard to fiscal policy and saving in the good years in order to spend in the bad ones is still not acceptable.' (Interview L2)

Like in Estonia, the adoption of the structural deficit rule has increased the density of coordinative discourse on fiscal policy and also empowered the role of the MoF officials in it. As the interviewed officials noted, the discussions on fiscal policy have become more technical, elaborate and extensive than before, facilitated also by the assessments of the EC and the Fiscal Council. The discursive interactions between the MoF officials and politicians have become denser since the officials have to explain the complexities involved in calculating the structural position and persuade the elected officials of the need to follow the established fiscal rule. In the words of one official, 'We can observe now, especially in the pre-election atmosphere, that the desire of the politicians not to comply with the fiscal policy targets is high. So we in the MoF serve the role of a watchdog, who's barking all the time, saying that you have to comply with the requirements, but there is willingness to trespass.' (Interview L2).

While in Estonia, the structural balance rule triggered extensive discussions in the communicative domain of fiscal policy discourse and also shifts in the content of the discourse, in Latvia, the issues related to the structural deficit have not led to significant change in communicative discourse.

\section{Which factors have influenced the discursive shifts?}

In both countries, the notion of using the structural budget position as a yardstick for fiscal policy - as required by the Fiscal Compact - ran counter to the existing policy legacies, which had focused on the nominal stance. Given the 'obsession' of the Estonian policymakers with nominal balance and their aversion to running deficits, the adaptational pressures were felt more strongly than in Latvia. In order to deal with those, the policy actors in Estonia resorted to 'layering' and 'bricolage', described in section 2, both in the coordinative and communicative domain. As mentioned above, the pre-existing policy legacies in Estonia had always required the government to balance the budget (in nominal terms). In order to persuade the politicians of the normative desirability of following the structural rather than the nominal balance, the civil servants 'layered' the idea of 'structural balance' on the pre-existing notion of 'a balanced budget'. This was facilitated by the fact that the new organic budget law requires structural budget balance (rather than stipulating a structural deficit limit). As one of the interviewed officials put it, 'Since in our society[,] the general idea is that the state budget should be balanced, the structural balance also resonates well with that.' (Interview E2). Also, in the coordinative discourse, it has been emphasized that the structural balance means that the budget would be balanced 'over the long term', which has enhanced its normative acceptability. The same arguments were then conveyed in the communicative discourse - in order to make the abandonment of the 'sacred principle' of a nominally balanced budget more palatable to the Estonian electorate, both in the legislative discussions and media articles.

The adoption of the structural budget rule has broadened the range of actors who contribute to the fiscal policy discourse, which, in turn, has increased the density of coordinative discourse in both countries, as noted by all interviewees. Via the European Semester, the EC has become more extensively involved in the budget preparation process of the member states (see Ioannou et al. 2015), and its assessments of the structural position of the draft budgets provide additional input to fiscal policy discussions. In Estonia and Latvia, the estimations of the EC have differed from those of their respective MoFs, which, in turn, has led to discussions over why these computations diverge. The Fiscal Compact also required the members of the Eurozone to establish independent fiscal councils, which evaluate the compliance with the structural deficit target - adding a further actor to participate in the coordinative discourse over fiscal policy (Raudla et al. 2018). In addition, the complexities involved in calculating the structural budget position have enhanced the role and the power of the finance ministries in the coordinative fiscal policy discourse in both countries. As some of the interviewees noted, only a couple of MoF officials understand what the structural balance actually entails, which gives them a more prominent position in fiscal policy discussions (Interviews E5, E6).

Indeed, in both countries, an important part in bringing about the ideational shifts described above was played by the MoF. Ministry officials took on the task of 'localizing' the new rule, first by formulating it in the organic budget law (in both countries the MoF officials wrote the new laws) and then by emphasizing it in the budgetary process. Our interviews indicate that even though they had originally been against including the structural target in the Fiscal Compact, once they had to implement it, the MoF officials increasingly advocated it as a normatively desirable policy stance in the domestic coordinative discourse and sought to persuade politicians of its acceptability. Since the crisis of 2008-2010, the MoF officials from both countries have been more intensively involved in the fiscal policy-making processes of the EU. In that light, we can conjecture that through the socialization mechanisms - 


\section{$\$$ sciendo}

interactions with the EU officials as well as elite networking with counterparts from other countries during the frequent meetings in Brussels (e.g., ECOFIN preparatory meetings) - that have accompanied this participation, the MoF officials in Estonia and Latvia have increasingly 'bought into' the idea of using structural position (rather than nominal stance) as the predominant yardstick in fiscal policy.

The experience of the crisis (2008-2010) ${ }^{7}$ in both countries mediated the effect of the structural deficit rule on domestic policy discourse in various ways. First, it allowed the policy actors (especially the MoF officials) in both countries to utilize the structural balance requirement to 're-interpret' the fiscal policies enacted before the crisis and to argue that if structural balance had been the yardstick for fiscal policies in 2004-2007, the bubble might have been smaller since the spending of windfall revenues would have been constrained. Second, since the experience of the crisis was more dramatic in Latvia (as it needed a bailout from the IMF and the EU), the structural deficit rule has provided its MoF officials with a focal point to argue for constraints on fiscal profligacy and 'budgetary irresponsibility'. In Estonia, however, where extensive austerity measures had been voluntarily adopted by the government (despite the existence of a sizable rainy-day fund), the structural balance rule has allowed for the emergence of a different interpretation: namely, that perhaps the austerity measures 'went too far' and in a major economic downfall, running deficits might be acceptable. Third, in both countries, the crisis experience further empowered the MoF officials as policy actors in coordinative policy discourse. During the crisis, the politicians had to increasingly rely on the finance ministries for gathering information about the budgetary developments during that time. Thus, all our interviews indicated that owing to the enhanced position of the MoF after the crisis, its officials felt that their arguments about the importance of the structural position in fiscal policy-making were being taken more seriously than they would be otherwise.

With regard to the nature of the rule, all interviewees in both countries considered the use of the structural target as a yardstick for fiscal policy very complex. They argued that the calculation of the structural position is complicated and hence it is hard for the politicians, media and ordinary citizens to understand what it actually encompasses. All the officials also agreed that there are significant uncertainties involved in estimating the structural deficit (or balance) because of the challenges in evaluating the cyclical position of the economy and the output gap. Given that the MoF and the EC use somewhat different models for estimating the output gap, their assessments of the structural position of the budget have diverged, triggering further discussions about fiscal policy. The complexity of the structural deficit rule has also contributed to enhancing the density of fiscal policy discourse in both countries and also empowered the MoF officials in the coordinative policy discourse vis-à-vis the politicians, since the civil servants have more information about the methodology involved in calculating the structural position than the politicians in the cabinet and the legislature. The interviewed civil servants in both countries noted that the insights they have about the structural position of the budget give them a stronger position in negotiating budgetary issues with the politicians. In the words of one interviewee, 'Because of the structural budget rule, the politicians need to listen to us more and more carefully and also have a lot more explaining to do than before.' (Interview E5).

Despite the inherent complexity of the structural budget rule, however, it has clearly exceeded the 'boredom' threshold and moved beyond coordinative discourse into communicative discourse in Estonia, though not so in Latvia. In order to explain that difference, we have to look at the role of the strategic interests of the elected officials. First, the structural balance rule entered communicative discourse because the new coalition government formed between the RP and the SD in Estonia in spring 2014 - one year ahead of the regular elections in 2015 - needed to justify the additional expenditures necessary to cover the promises of the new coalition agreement. At the same time, the economic outlook worsened, due to the developments in the external environment (especially the crisis in Ukraine). Maintaining a nominal balance, therefore, became challenging and hence the new coalition promised to keep the budget in structural balance (or even surplus) while running a nominal deficit. Second, the entrance of the structural balance rule to the communicative discourse was facilitated by the strategic interests of fiscally conservative opposition party (PPRU) to attack the government for adopting a budget with a projected deficit. The MPs from PPRU also used the divergence between the EC and the MoF estimates to accuse the government of violating the structural balance requirement (Verbatim Record 4 June 2014,19 November 2014; 10 December 2014). This divergence in estimates provided them with additional ammunition in claiming that nominal balance is in fact a better normative yardstick for fiscal policy.

7 For a more detailed description of how the two countries experienced and dealt with the crisis, see Raudla and Kattel (2011) and Kattel and Raudla (2013). 


\section{Conclusion}

The goal of our paper has been to explore, both theoretically and empirically, which factors influence the discursive impacts of EU rules in the member states. Given the growing role of the EU in the political lives of its member states, this question is increasingly important. The literature on DI has demonstrated that discursive shifts can contribute significantly to actual policy changes (Schmidt 2008, 2010, 211). Hence, by tracing discursive shifts - resulting from the EU rules - we are able to better understand which mechanisms shape policy developments in the long term.

Our research about Estonia and Latvia shows that in the case of the structural deficit target prescribed by the Fiscal Compact, the EU played an important role of ideational authority. Based on historical institutionalism (e.g., Pierson 2000) and the Europeanization literature (e.g., Börzel and Risse 2003), we would have expected the fiscal policy discourse in these two countries to remain unchanged - since the new rule clashed with the existing notions of fiscal policy-making. However, our empirical analysis indicates that although the two countries would not have voluntarily adopted the structural deficit rule, once it was enacted, it did bring about significant shifts both in the ideational and interactive domains of discourse - in a way that went beyond just 'formal' compliance with an externally mandated rule. Before the adoption of the structural deficit rule, the focus of fiscal policy-making in both countries had been on nominal balance, and the policy actors had been sceptical of using the budget for stabilizing the economy in a counter-cyclical way, subscribing instead to a pro-cyclical approach. After the adoption of the new rule, however, the structural position of the budget has become the main focus in fiscal policy-making and the officials consider it normatively more acceptable to use the budget for macroeconomic stabilization.

There were some differences in the direction of the ideational shifts in the two countries we examined, depending on their starting points and on how the countries had experienced and managed the recent crisis (in 2008-2010). In Estonia, the shift has been from fiscal policy discussions that concentrated on maintaining nominal balance and avoiding deficits to deliberations, where (at least) some consideration has been given to the possibility of using the budget for smoothing the economic cycle. In the Latvian case, however, where the government has recorded budget deficits in most years since 2000, the adoption of the new fiscal rule has driven home the arguments about being 'fiscally responsible' and avoiding 'overspending' - buttressed by the traumatic bailout experience. Thus, in Latvia, the structural deficit rule has been viewed as providing additional restrictions on fiscal policy-making, whereas in Estonia, it has had a 'relaxing effect' on fiscal policy discourse.

With regard to the interactive dimension, the structural balance rule had similar effects on coordinative discourse in Estonia and Latvia. In both countries, the fiscal policy discussions in the coordinative domain have become more elaborate, in terms of the range of policy alternatives considered and the density of discursive interactions. We found, however, that while the notion of structural balance has entailed shifts in the communicative domain in Estonia, it has not done so in Latvia.

With regard to the factors that have influenced the discursive shifts, our cases indicate that the factors outlined in out theoretical discussion - 'layering', changes in the numbers and types of policy actors, the 'translating' role of civil servants, the nature of the rule, the experience of a crisis and the strategic interests of policy actors - played a significant role. We also found that the various mediating factors can interact in significant ways - and, hence, they should be considered in tandem rather than in an isolated way in future empirical analyses.

In particular, in both cases, an important role in 'localizing' the EU rule was played by civil servants (i.e., the MoF officials), who, through their extensive involvement at the EU meetings became, after the adoption of the new rule, active advocates of using the structural position vis-à-vis the politicians in the coordinative policy discourse. In both countries, the experience of the crisis and the complex nature of the externally imposed rule enhanced the positions of the finance ministries in fiscal policy-making (vis-à-vis politicians in the cabinet and in the parliament), which allowed them to assume a stronger role in the coordinative fiscal policy discourse and facilitated the emergence of more sophisticated discussions on fiscal policy. The development of more elaborate coordinative discourse was further boosted by the participation of additional actors in discussions over the budget - the European Commission and the independent fiscal councils - who play a role in observing the compliance with the structural balance.

In the Estonian case, the discursive shifts also reflected the efforts of policy actors to 'layer' the new rule onto existing policy legacies by claiming that the focus on 'structural balance' is essentially a more 'sophisticated' version of adhering to the principle of balanced budget, which had been the hallmark of Estonian fiscal policy since the 1990s. 
An important difference between our two cases is that while the adoption of the structural deficit rule - which is highly complex and technical - led to shifts in coordinative discourse in both countries, the shift in communicative discourse could only be observed in Estonia but not in Latvia. This indicates that even if the nature of the EU rule is highly complex, it can lead to shifts in communicative policy discourse when the partisan actors have a clear strategic interest in bringing it up. On the one hand, the new governing coalition used the structural balance to justify additional pre-election expenditures resulting in nominal deficit. On the other hand, an opposition party used the government's shift of focus from nominal to structural budget balance to criticize the governing coalition and accused it of breaking with the established tradition of fiscal conservatism.

In sum, the theoretical contribution of our article was to continue the discussion - initiated by Schmidt and Radaelli (2004) - geared at synthesizing the insights from the DI and Europeanization literatures and to consider more systematically the different factors that mediate the effects of an EU rule on domestic policy discourse. We believe the analytical framework we have developed outlining the types of discursive shifts and explaining which factors mediate them - provides a useful starting point for future empirical studies that want to make use of the DI perspective in the context of Europeanization and to explore the effects of EU rules in a more nuanced way than just focusing on policy changes per se.

Our case studies of Estonia and Latvia indicate that the factors delineated in our theoretical framework can indeed play an important role in shaping the discursive shifts. Also, our empirical analysis demonstrates that the factors discussed in the analytical framework have to be examined in tandem rather than in isolation, since there are important interactions between them. Thus, future studies should pay close attention to such factor configurations and the interaction effects rather than exploring the impacts of factors in isolation. At the same time, it is important to keep in mind that the list of factors we have outlined is not exhaustive and future studies can certainly explore more extensive taxonomies. Future comparative studies could expand the range of countries covered. The focus in this paper was on small countries that are highly pro-European, and hence, the generalizability of our findings to other EU countries that are bigger or more sceptical of the EU can be limited. Also, the specific discursive impacts of the structural deficit rule are likely to depend on historical fiscal policy legacies, which vary considerably between the EU countries.

\section{ACKNOWLEDGEMENTS}

Funding for this research was received from the Estonian Research Council grants IUT19-13, PUT-1142 and Norwegian Financial Mechanism 2009-2014 under project No EMP264.

\section{REFERENCES}

Barnett, M., and M. Finnemore. (2004). Rules for the World: International Organizations in Global Politics. Cornell University Press.

Béland, D., and R.H. Cox. eds. (2011). Ideas and Politics in Social Science Research. New York: Oxford University Press.

Blyth, M. (2002). Great Transformations. New York: Cambridge University Press.

Blyth, M. (2007). 'Powering, Puzzling, or Persuading? The Mechanisms of Building Institutional Orders.' International Studies Quarterly 51: 761-777.

Börzel, T. and T. Risse (2003). 'Conceptualising the Domestic Impact of Europe.' In K. Featherstone and C.M. Radaelli (eds.), The Politics of Europeanisation. Oxford: Oxford University Press, pp. 57-80.
Busch, A. (2004). 'National Filters: Europeanisation, Institutions, and Discourse in the Case of Banking Regulation.' West European Politics 27(2): 310-333.

Campbell, J.L. (2004). Institutional Change and Globalization. Princeton: Princeton University Press.

Campbell, J.L. (1998). 'Institutional Analysis and the Role of Ideas in Political Economy.' Theory and Society 27(3): 377-409.

Carstensen, M.B. (2011). 'Paradigm Man vs. the Bricoleur: Bricolage as an Alternative Vision of Agency in Ideational Change.' European Political Science Review 3(1): 147-167.

Cowles, M.G., J. Caporaso and T. Risse, eds. (2001). Europeanization and Domestic Change. Ithaca, NY: Cornell University Press. 
Crespy, A. and V. Schmidt (2014). 'The Clash of Titans: France, Germany and the Discursive Double Game of EMU Reform.' Journal of European Public Policy 21(8): 1085-1101.

Gutierrez, R.A. (2010). "When Experts Do Politics: Introducing Water Policy Reform in Brazil." Governance 23(1): 59-88.

Hansalu, K. (2014). 'Seeder: valitsus varjas 300 miljoni euro suurust eelarveauku' [Seeder: The Government Hid the Budget Gap of 300 million euros] Postimees 11.11.2014 https://majandus24.postimees.ee/2987351/ seeder-valitsus-varjas-300-miljoni-euro-suurust-eelarveauku? ga $=2.110450817 .509292523 .1530467781-1640312357.1465566974$

Ioannou, D., P. Leblond, and A. Niemann. (2015). 'European Integration and the Crisis: Practice and Theory.' Journal of European Public Policy 22(2): 155-176.

Irvine, J.A.S. (2011). 'Canadian Refugee Policy: Understanding the role of international bureaucratic networks in domestic paradigm change.' In G. Skogstad (ed), Policy Paradigms, Transnationalism, and Domestic Politics. Toronto: University of Toronto Press.

Kattel, R. and R. Raudla. (2013). 'The Baltic States and the Crisis of 20082011.' Europe-Asia Studies 65(3): 426-449.

Lynggaard, K. (2012). 'Discursive Institutional Analytical Strategies.' In C.M. Radaelli and T. Exadaktylos (eds) Research Design in European Studies. Palgrave Macmillan.

Lütz, S. and M. Kranke (2014). 'The European Rescue of the Washington Consensus? EU and IMF lending to Central and Eastern European Countries.' Review of International Political Economy 21(2): 310-338

Mourre, G., C. Astarita and S. Princen. (2014). Adjusting the Budget Balance for the Business Cycle: The EU Methodology, European Economy: Economic Papers, no. 536, European Commission.

Nael, M. (2014) 'Ligi: prognoosi muutumisele ei pea tingimata kärpega reageerima.' [Ligi: The Change in the Prognosis does not Necessitate Cutbacks] Estonian Public Broadcasting. http://uudised.err.ee/v/ majandus/75bbdg7b-d3od-4290-a267-c86606393bag

Radaelli, C.M. (2003). 'The Europeanisation of Public Policy.' In The Politics of Europeanisation, Oxford University Press, Oxford, pp. 27-56.

Raudla, R. and R. Kattel. (2013). 'Fiscal Stress Management during the Financial and Economic Crisis: The Case of the Baltic Countries.' International Journal of Public Administration 36(10): 732-742.

Raudla, R. and R. Kattel. 2011. 'Why Did Estonia Choose Fiscal Retrenchment after the 2008 Crisis?' Journal of Public Policy 31(2): 163186.
Raudla, R., K. Keel, and M. Pajussaar. (2018). 'The Creation of the Fiscal Council in Estonia: Exploring the Explanations for Its Institutional Design.' Public Budgeting \& Finance 38(2): 61-80.

Risse, T., M. Cowles, and J. Caporaso. (2001). 'Europeanization and Domestic Change.' In Transforming Europe. Europeanization and Domestic Change, Cornell University Press, London.

Schmidt, V.A. (2002). 'Europeanization and the Mechanics of Economic Policy Adjustment.' Journal of European Public Policy 9(6): 894-912.

Schmidt, V.A. (2008). 'Discursive Institutionalism: The Explanatory Power of Ideas and Discourse.' Annual Review of Political Science 11: 303-326.

Schmidt, V.A. (2009). 'Putting the Political back into Political Economy by Bringing the State Back in yet Again.' World Politics 61(3): 516-546.

Schmidt, V.A. (2010). 'Taking Ideas and Discourse Seriously: Explaining Change through Discursive Institutionalism as the Fourth New Institutionalism.' European Political Science Review 2(1): 1-25.

Schmidt, V.A. (2014). 'Speaking to the Markets or to the People? A Discursive Institutionalist Analysis of the EU's Sovereign Debt Crisis.' The British Journal of P \& International Relations 16(1): 188-209.

Schmidt, V.A. and C.M. Radaelli. (2004). 'Policy Change and Discourse in Europe: Conceptual and Methodological Issues.' West European Politics 27(2): 183-210.

Sester, S. (2014a). 'Riigi uus eelarvestrateegia tuleb ümber vaadata.' [The New State Budget Strategy Needs to be Revised] Postimees 12.04.2014 http://majandus24.postimees.ee/2758732/sester-riigi-uuseelarvestrateegia-tuleb-umber-vaadata

Sester, S. (2014b). 'Selle raha me sööme ära.' [This Money will be Eaten] Äripäev 09.04.2014 http://www.aripaev.ee/uudised/2014/04/09/selleraha-me-soome-ara

Skogstad, G. and V.A. Schmidt. (2011). 'Introduction: Policy Paradigms, Transnationalism, and Domestic Politics.' In G. Skogstad (ed), Policy Paradigms, Transnationalism, and Domestic Politics. Toronto: University of Toronto Press.

Trondal, J. (2001). 'Is there any Social Constructivist-Institutionalist Divide? Unpacking Social Mechanisms affecting Representational Roles among EU Decision-Makers.' Journal of European Public Policy 8(1): 1-23.

Tubalkain, M. 2014. 'Ligi: riik parandab inimese elujärge majandust tasakaalus hoides' [Ligi: The State Improves People's Lives by Balancing the Economy] Postimees 22.10.2014 https://majandus24. postimees.ee/2963763/ligi-riik-parandab-inimese-elujarge-majandusttasakaalus-hoides?_ga=2.45962528.509292523.15304677811640312357.1465566974 


\section{sciendo}

Interviews with Ministry of Finance officials

Estonia

E1: 18.08.2014

E2: 09.09.2014

E3: 09.09.2014.

$E_{4}: 10.09 .2014$

$E_{5}: 04.05 .2015$

E6: 04.05.2015

Latvia

L1: 17 September 2014

L2: 17 September 2014

L3: 20 October 2014

L4: 5 June 2015

L5: 13 October 2015 